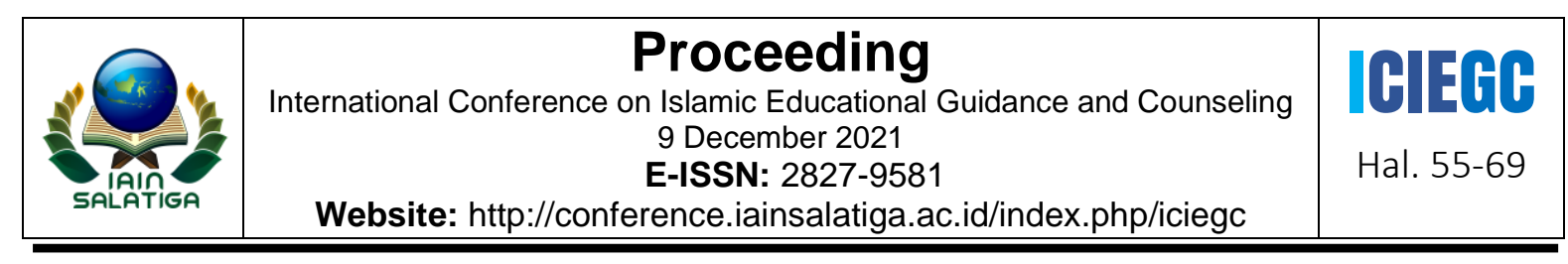

\title{
BIMBINGAN KEAGAMAAN MELALUI TEKNIK MENULIS PADA SISWA MUSLIM DI PERBATASAN INDONESIA-MALAYSIA, KALIMANTAN BARAT
}

\author{
Saripaini $^{1}$, Hesty Nurrahmi ${ }^{2}$ \\ ${ }^{1}$ UIN Sunan Kalijaga \\ ${ }^{2}$ IAIN Pontianak
}

\begin{tabular}{l}
\hline Informasi Artikel \\
\hline Penulis Korespondensi: \\
Hesty Nurrahmi \\
Email: \\
hestynurrahmi@iainptk.ac.id
\end{tabular}

\begin{abstract}
Religion or belief is a human nature. However, the nature of religion does not develop just like that. There are other elements that contribute to influencing the actions of individuals in religion. Individuals of adolescent age have great potential to face more complex religious problems. On the one hand, adolescents are under the influence of the social space that surrounds them, and on the other hand they will encounter unstable psychological conditions. This paper aims to find out about religious guidance through writing techniques for Muslim students on the Indonesia-Malaysia border (Badau-Lubok Antu), West Kalimantan. The study was conducted on class XI students of SMA Negeri 1 Badau for the 2019/2020 academic year. Religious guidance is designed into 2 cycles in 6 meetings. The guidance group consists of 7 students. The research data was obtained through the results of students' writings/narrative texts and interviews. The data are presented qualitativelydescriptively. The results showed that there was religious awareness in Muslim students of SMA Negeri 1 Badau after following group guidance. Group members are able to identify and realize the problems they are facing.
\end{abstract}

\begin{tabular}{l}
\hline Keyword: Writing technique; religious guidance \\
\hline ABSTRAK \\
Beragama atau berkeyakinan merupakan satu fitrah bagi manusia. \\
Akan tetapi fitrah beragama tidak berkembang begitu saja. Ada unsur \\
lain yang turut andil mempengaruhi tindakan induvidu dalam \\
beragama. Individu usia remaja berpontensi besar untuk menghadapi \\
permasalahan keagamaan yang lebih kompleks. Di satu sisi remaja \\
berada dalam pengaruh ruang sosial yang melingkunginya, dan di sisi \\
lain mereka akan menemui kondisi psikologis yang tidak stabil. \\
Tulisan ini bertujuan untuk mengetahui tentang bagaimana \\
bimbingan keagamaan melalui teknik menulis pada siswa muslim di \\
perbatasan Indonesia-Malaysia (Badau-Lubok Antu), Kalimantan \\
Barat. Penelitian dilakukan terhadap siswa kelas XI SMA Negeri 1 \\
Badau tahun ajaran 2019/2020. Bimbingan keagamaan dirancang \\
menjadi 2 siklus dalam 6 kali pertemuan. Kelompok bimbingan \\
terdiri dari 7 orang siswa. Data penelitian diperoleh melalui hasil \\
tulisan/teks narasi siswa dan wawancara. Data-data dipaparkan \\
secara kualitatif-deskriptif. Hasil penelitian menampilkan bahwa \\
Adanya kesadaran beragama pada siswa muslim SMA Negeri 1 \\
Badau setelah mengikuti bimbingan kelompok. Anggota kelompok \\
mampu megenali dan menyadari permasalahan yang tengah mereka \\
hadapi.
\end{tabular}


Kata kunci: Teknik menulis; bimbingan keagamaan

\section{PENDAHULUAN}

Badau merupakan satu dari 23 kecamatan yang ada di Kabupaten Kapuas Hulu, Kalimantan Barat. Secara administratif kawasan ini menjadi Kecamatan pada tahun 1961. 2, $35 \%$ dari Kabupaten Kapuas Hulu merupakan wilayah Badau dengan luas wilayah +700 km2. Secara teritorial sebelah Utara Kecamatan Badau berbatasan dengan Distrik Lubok Antu, Sriaman, Negara Serawak, Malaysia. Karena batas Utara berbatasan langsung dengan distrik Malaysia wilayah Badau dikenal sebagai wilayah perbatasan langsung. Pintu gerbang atau border terletak di jalan PLBN (Pos Lintas Batas Negara) lebih kurang $1 \mathrm{KM}$ dari pusat Kecamatan Nanga Badau.

Masyarakat di Kecamatan Badau terdiri dari beragam suku, yakni; Dayak, Melayu, Tionghoa, Jawa, dan Sunda. Sementara itu ada tiga agama yang mendominasi kawasan Badau di antaranya Islam, Khatolik dan Protestan dan ada kepala keluarga yang memeluk agama Budha. Keragaman agama dan etnis di dalam suatu kelompok masyarakat memunculkan suatu corak yang dikonstruksi dari beragam budaya. Hal ini dapat menimbulkan kebingungan dalam mengambil sikap antara budaya dan agama. Hal ini dapat menjadi salah satu penyebab munculnya problem keagamaan di dalam masyarakat.

Secara umum Faqih (2001) mengemukakan enam problem keagamaan dalam kehidupan manusia; (1) problem ketidakberagamaan;(2) problem pemilihan agama; (3) problem kegoyahan iman; (4) problem karena perbedaan paham dan pandangan; (5) problem ketidak pahaman mengenai ajaran agama; (6) problem pelaksanaan ajaran agama. Sementara itu pada usia remaja seorang akan menemui kondisi psikologis yang memicu terjadinya masalah keagamaan, di antaranya; (1) pertumbuhan pikiran dan mental, (2) perkembangan perasaan, (3) pertimbangan sosial, (4) perkembangan moral (Arifin, 2008).

Adapun problem keagamaan yang yang berlaku pada siswa muslim di Badau ada tiga, yakni; problem kesulitan dalam menjalankan agama, problem kelemahan iman, dan problem pelaksanaan ajaran agama. Sementara itu sikap yang umumnya ditunjukkan oleh siswa muslim di SMA Negeri 1 Badau terhadap problem keagamaan adalah percaya turutturutan, percaya dengan kesadaran, percaya tapi agak ragu-ragu (Saripaini, 2020).

Sebagai Makhluk Tuhan sekaligus makluk sosial problem tersebut bukanlah perkara sepele, apabila tidak ada respon preventif untuk menghadapi permasalahan yang datang, maka dapat diperkirakan remaja akan menemui penyimpangan dari potensi fitrahnya 
(beriman kepada Tuhan yang Maha Esa). Hal demikian tentu akan berdampak buruk terhadap hasil penemuan identitas diri sebagai pribadi buruk yang akan mempengaruhi kehidupan di masa dewasa kelak.

Untuk menghadapi berbagai masalah, siswa membutuhkan bantuan untuk merefleksikan ide, pikiran, dan perasaan sehingga mereka menyadari keabsahannya. Kemudian mengenali keinginan untuk kembali kepada kebenaran sejati (Allah). Pemberian bantuan melalui bimbingan keagamaan haruslah dikemas secara profesional. Dengan kata lain, dakwah (bimbingan) harus tampil secara aktual dan faktual berdasarkan analisis terhadap problem keagamaan dan objek yang akan dihadapi. Proses bimbingan dan konseling tidak hanya lebih dari sekadar bicara, tetapi seringkali perlu dilakukan Jacobs (1994). Keberadaan teknik kreatif dalam konseling membantu konseli agar lebih aktif dalam proses pencegahan atau pun menyelesaikan permasalannya. Ada berbagai teknik kreatif yang biasa digunakan konselor, satu di antaranya adalah teknik menulis.

Menulis untuk terapi mulai dikenalkan oleh Pannebaker and Beall pada tahun 1986 melalui sebuah penelitian yang dilakukan pada 40 mahasiswa (Pannebaker \& Beall, 1986). Penelitian tersebut dilakukan bertujuan untuk mengetahui bahwa menulis dapat dijadikan media pelepasan emosi dan stres. Selanjutnya pengembangan teknik menulis sebagai upaya pemberian bantuan telah dilakukan melalui beberapa riset (Susanti \& Supriantini, 2013; Lestari \& Eliyanti, 2014; Samsudin, 2018; Karyanti \& Setiawan, 2019).

Secara definitif teknik menulis adalah sebuah teknik yang menggunakan proses menulis untuk mengungkapkan sesuatu perkara yang terpendam. Selanjutnya menulis ekspresif dapat diartikan sebagai teknik melepas tekanan mental atau emosi dan juga dikenal dengan nama mental house cleaning (Gunawan, 2012). Berikutnya dapat dipahami bahwa teknik menulis merupakan suatu langkah mengungkapkan suatu peristiwa, emosi, perasaan yang terpendam agar dapat dipahami, dimengerti yang bertujuan untuk melepaskan tekanan mental.

Dalam pengaplikasian teknik menulis untuk mengatasi problem beragama pada usia remaja (siswa) akan lebih tepat bila dilakukan malui setting kelompok, ini bertujuan untuk membantu konseli atau individu agar aktif, dinamis dalam berkomunikasi (Konadi, dkk., 2017). Dalam konseling kelompok konseli dapat berlatih untuk dapat menerima diri sendiri dan orang lain serta meningkatkan pikirannya (Kurnanto, 2014). Model bimbingan kelompok dipilih berdasarkan pertimbangan bahwa remaja akan lebih senang berdiskusi, berdebat di dalam suatu kelompok dari pada mendapatkan sekadar penjelasan bersifat 
pengecapan atau pun pemberian doktrin (Subandi, 2013). Sejalan dengan itu Geldard \& Geldard (2015) menyatakan bahwa cara terbaik untuk membantu seseorang adalah memberinya waktu untuk secara seksama mempertimbangkan solusi-solusinya sendiri.

Berdasarkan latar belakang di atas, maka tulisan ini akan memberikan gambaran bagaimana hasil pelaksanaan bimbingan keagamaan melalui teknik menulis yang diberikan kepada siswa muslim di perbatasan Indonesia-Malaysia (Badau-Lubok Antu), Kalimantan Barat.

\section{METODE}

Jenis penelitian ini adalah penelitian kualitatif yang akan menghasilkan data deskriptif berupa kata-kata yang menguraikan, memaparkan dan menerangkan data-data yang diperoleh dari lapangan. Metode yang digunakan dalam penelitian ini adalah metode penelitian tindakan (action research) yakni cara suatu kelompok atau seseorang dalam mengorganisasi suatu kondisi sehingga mereka dapat mempelajari pengalaman mereka dan membuat pengalaman mereka dapat diakses oleh orang lain (Prastowo, 2011). Penelitian akan menggunakan model kemmis.

Pengumpulan data dilakukan sejak 17 Juli - 24 Agustus 2019 saat program Kuliah Kerja Nyata $(\mathrm{KKN})$ Kebangsaan dilaksanakan di Kecamatan Badau Kabupaten Kapuas Hulu, Kalimantan Barat. Penelitian ini dilakukan di SMA Negeri 1 Badau. Instansi pendidikan pemerintah yakni Sekolah Menegah Atas (SMA) dipilih karena merupakan salah satu tempat berkumpulnya remaja dari berbagai desa di Kecamatan Nanga Badau, Kabupaten Kapuas Hulu. Kehidupan siswa muslim di SMA Negeri 1 Badau merupakan salah satu contoh lingkungan keagamaan yang banyak menampilkan problem keagamaan siswa muslim di kawasan Nanga Badau, perbatasan Indonesia-Malaysia yang terletak di Kabupaten Kapuas Hulu, Kalimantan Barat. Di mana kebudayaan masyarakat muslim bukanlah satu-satunya kebudayaan yang berkembang di lingkungan tempat tinggal.

Bimbingan keagamaan dilaksanakan dalam 2 siklus. Setiap siklus terdiri dari 3 kali pertemuan dengan alokasi waktu 1 x 60 menit setiap pertemuan. Observasi dan evaluasi dilaksanakan setiap kali pertemuan, setiap treatment yang diberikan adalah proses penuangan masalah dan dilanjutkan dengan mendiskusikan tema yang telah ditulis sebagai evaluasi. Pemberian tema berbeda dilakukan dalam 1 siklus, pada siklus kedua anggota kelompok akan diberikan tema tulisan dan diskusi yang sama dengan siklus pertama. Berikut ini akan dijelaskan tahapan-tahapan penelitian tindakan yang akan dilakukan, sebagai berikut: 
1. Tahap awal adalah observasi dan wawancara untuk memperoleh gambaran tentang kondisi objektif lapangan.

2. Tahap kedua adalah pembentukan kelompok bimbingan keagamaan yang terdiri dari 7 siswwa muslim kelas 11 di SMA Negeri 1 Badau.

3. Tahap ketiga adalah pengembangan teknik menulis melalui bimbingan kelompok untuk mencegah problem keagamaan. pedoman pelaksanaan teknik menulis melalui bimbingan kelompok yang dilaksanakan di SMA Negeri 1 Badau tercantum dalam tabel 1.

4. Tahap ke empat adalah implementasi teknik menulis untuk mencegah problem kegamaan siswa muslim kelas 11 di SMA Negeri 1 Badau.

\section{Tabel 1: Pedoman Pelaksanaan Teknik Menulis melalui Bimbingan Kelompok Siklus 1 dan Siklus 2}

\begin{tabular}{|c|c|c|c|}
\hline $\begin{array}{c}\text { Tema } \\
\text { Pertemuan }\end{array}$ & Arahan Siklus 1 & Arahan Siklus 2 & $\begin{array}{c}\text { Materi/bahan } \\
\text { diskusi }\end{array}$ \\
\hline $\begin{array}{l}\text { Pengenalan } \\
\text { diri }\end{array}$ & $\begin{array}{l}\text { 1. Apa yang kalian benci } \\
\text { 2. Apa yang kalian sukai } \\
\text { 3. Siapa diriku } \\
\text { 4. Apa tujuan hidupku } \\
\text { 5. Apa yang aku inginkan } \\
\text { 6. Apa yang aku miliki } \\
\text { 7. Apa itu sukses } \\
\text { 8. Apa yang aku hargai } \\
\text { 9. Perlukah aku berubah untuk } \\
\text { mencapai kesuksesanku? } \\
\text { Mengapa? } \\
\text { 10. Apa yang harus rubah? }\end{array}$ & $\begin{array}{l}\text { 1. Apa yang aku benci } \\
\text { 2. Apa yang aku sukai } \\
\text { 3. Siapa diriku } \\
\text { 4. Apa tujuan hidupku } \\
\text { 5. Apa yang aku inginkan } \\
\text { 6. Apa yang akau miliki } \\
\text { 7. Apa itu sukses } \\
\text { 8. Apa yang aku hargai } \\
\text { 9. Perlukah aku berubah } \\
\text { untuk mencapai } \\
\text { kesuksesanku? Mengapa? } \\
\text { 10. Apa yang harus rubah? }\end{array}$ & \\
\hline $\begin{array}{l}\text { Apa itu } \\
\text { agama }\end{array}$ & $\begin{array}{l}\text { 1. Ceritakan pengalaman } \\
\text { beragama yang paling } \\
\text { berkesan. } \\
\text { 2. Apa dampaknya terhadap } \\
\text { diriku? } \\
\text { 3. Di mana posisi Tuhan ketika } \\
\text { aku berada di dalam } \\
\text { masalah? }\end{array}$ & $\begin{array}{l}\text { 1. Apa dampaknya terhadap } \\
\text { diri anda? } \\
\text { 2. Dimana posisi Tuhan } \\
\text { ketika aku berada di } \\
\text { dalam masalah? } \\
\text { 3. Apa yang aku inginkan? } \\
\text { 4. Apa yang aku lakukan? } \\
\text { 5. Apa yang aku rasakan? }\end{array}$ & $\begin{array}{l}\text { Bantuan } \\
\text { memahami } \\
\text { fitrah manusia }\end{array}$ \\
\hline $\begin{array}{l}\text { Mengapa } \\
\text { harus } \\
\text { berdoa }\end{array}$ & $\begin{array}{l}\text { 1. Ibadah apa saja yang biasa } \\
\text { dilakukan? } \\
\text { 2. Mengapa aku beribadah? } \\
\text { 3. Apa yang akan aku lakukan? } \\
\text { 4. Apa yang aku rasakan ketika } \\
\text { meninggalkan Allah? }\end{array}$ & $\begin{array}{l}\text { 1. Ceritakan pengalaman } \\
\text { beribadah yang biasa } \\
\text { dilakukan selama sebualan } \\
\text { terakhir? } \\
\text { 2. Mengapa aku beribadah? } \\
\text { 3. Apa yang akan aku } \\
\text { lakukan? } \\
\text { 4. Apa yang aku rasakan } \\
\text { ketika meninggalkan } \\
\text { Allah? }\end{array}$ & $\begin{array}{l}\text { Bantuan } \\
\text { memahami } \\
\text { dzikir dan doa }\end{array}$ \\
\hline
\end{tabular}


5. Tahap kelima adalah pengevaluasian hasil tulisan dan diskusi setiap pertemuan sebagai evaluasi setiap siklus pelaksanaan treatment. Yang kemudian dijadikan bahan evaluasi secara keseluruhan. Setiap diakhir siklus dilakukan evaluasi .

Membuat kesimpulan berdasarkan hasil teknik menulis yang telah dilakukan pada 7 orang konseli. Penarikan kesimpulan dilakukan berdasarkan tulisan-tulisan yang telah ada.

\section{HASIL DAN BAHASAN}

\section{Gambaran Umum Subjek Penelitian}

Penelitian ini melibatkan siswa muslim di SMA Negeri 1 Badau sebagai subjek penelitian (anggota kelompok), yakni siswa-siswi kelas XI tahun ajaran 2019/2020 yang secara umum telah berdomisili di Kecamatan Nanga Badau. Kelas XI dipilih karena dianggap lebih leluasa dan bisa mengikuti bimbingan kelompok, sebab jika mengambil siswa kelas X, mereka masih masa orienstasi, sementara kelas XII akan mempersiapkan diri menghadapi ujian nasional. SMA Negeri 1 Badau merupakan satu-satunya lembaga pendidikan sekolah menegah atas negeri yang ada di Kecamatan Nanga Badau, dengan 236 siswa. SMA Negeri 1 Badau terdiri dari 9 kelas dengan rincian 3 kelas IPA dan 6 kelas IPA, kemudian jumlah siswa berdasarkan jenis kelamin adalah 120 siswa laki-laki, 116 siswa perempuan, secara rinci dalam tabel 2. Sementara itu data siswa menurut agama dan kepercayaan di SMA Negeri 1 Badau tahun 2019, jumlah pemeluk agama Islam 130 siswa, Khatolik 88 siswa, Protestan 17 siswa, Budha 1 siswa, presentase data tersebut dapat dilihat pada diagram 1 .

Tabel 2

Jumlah Siswa SMA Negeri 1 Badau

\begin{tabular}{ccccc}
\hline \multirow{2}{*}{ No } & \multirow{2}{*}{ Kelas } & \multicolumn{2}{c}{ Jumlah Siswa } & \multirow{2}{*}{ Jumlah } \\
\cline { 2 - 4 } & Laki-laki & Perempuan & 30 \\
\hline 1. & X IPA & 15 & 15 & 33 \\
\hline 2. & X IPS 1 & 15 & 18 & 33 \\
\hline 3. & X IPS 2 & 22 & 11 & 25 \\
\hline 4. & XI IPA & 14 & 11 & 29 \\
\hline 5. & XI IPS 1 & 16 & 13 & 25 \\
\hline 6. & XI IPS 2 & 15 & 10 & 17 \\
\hline 7. & XII IPA & 6 & 11 & 24 \\
\hline 8. & XII IPS 1 & 10 & 14 & 20 \\
\hline 9. & XII IPS 2 & 7 & 13 & 236 \\
\hline & Jumlah & 120 & 116 &
\end{tabular}

Sumber: Data SMA Negeri 1 Badau, tahun 2019 


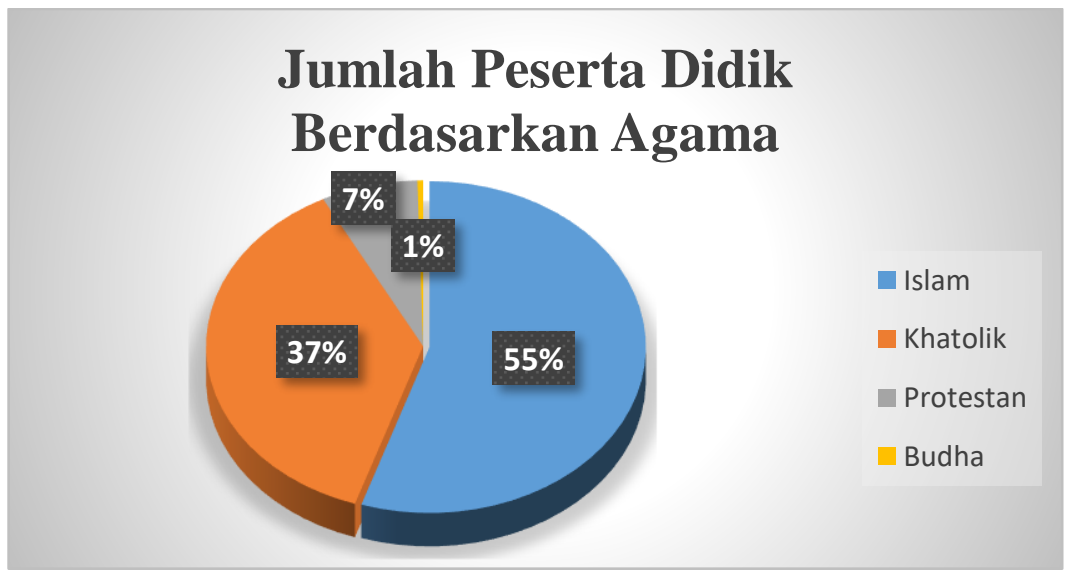

Diagram 1. Jumlah Peserta Didik Berdasarkan Agama

Kelompok bimbingan dibentuk dengan anggota 7 orang siswa kelas XI SMA Negeri 1 Badau. Siswa yang menjadi anggota kelompok bimbingan adalah siswa yang dipilih oleh guru agama Islam SMA Negeri 1 Badau.

Secara keseluruhan siswa kelas XI SMA Negeri 1 Badau ada 79 siswa, yang terdiri 29 siswa muslim dengan rincian 8 siswa kelas XI IPA, 12 siswa kelas XI IPS 1 dan 9 siswa dari kelas XI IPS 2. Tujuh (7) orang diambil mewakili tiap-tiap kelas XI, yaitu; 3 orang dari kelas XI IPA, 2 orang dari kelas XI IPS 1, dan 2 orang kelas XI IPS 2. Siswa yang dipilih merupakan individu yang tengah berada di fase kehidupan remaja dengan rentang usia 1517 tahun, beragama Islam, direkomendasikan oleh guru agama dan bersedia mengikuti proses bimbingan. Secara rinci daftar nama anggota kelompok tercantum dalam tabel 3. Tujuh siswa yang diambil merupakan siswa kelas dari latar belakang keluarga muslim dan saat ini telah berdomisili di Kecamatan Nanga Badau, dapat dilihat pada tabel 4.

Tabel 3: Daftar Nama Anggota Kelompok Bimbingan Berdasarkan Umur dan Kelas

\begin{tabular}{clcc}
\hline No. & \multicolumn{1}{c}{ Nama } & Umur $(\mathbf{T h})$ & Kelas \\
\hline 1. & Adiel Candra & 15 & XI IPA \\
\hline 2. & Nur Fadila & 15 & XI IPA \\
\hline 3. & Dwi Putri & 17 & XI IPA \\
\hline 4. & Erni Aprianti & 17 & XI IPS 1 \\
\hline 5. & Jumanah Ashari & 16 & XI IPS 1 \\
\hline 6. & Reski Raka Siwi & 16 & XI IPS 2 \\
\hline 7. & Pendi Supendi & 15 & XI IPS 2 \\
\hline
\end{tabular}


Tabel 4: Biodata Anggota Bimbingan Kelompok

\begin{tabular}{|c|c|c|c|c|c|c|}
\hline \multirow[b]{2}{*}{ No. } & \multirow[b]{2}{*}{ Nama } & \multirow{2}{*}{$\begin{array}{c}\text { Tempat } \\
\text { tanggal } \\
\text { Lahir }\end{array}$} & \multirow[b]{2}{*}{ Alamat } & \multicolumn{2}{|c|}{ Agama } & \multirow[b]{2}{*}{ Suku } \\
\hline & & & & Ayah & Ibu & \\
\hline 1. & Adiel Candra & $\begin{array}{l}\text { Pontianak } \\
1 \text { Oktober } \\
2003\end{array}$ & Badau Hilir & Islam & Islam & Melayu \\
\hline 2. & Nur Fadila & $\begin{array}{l}\text { Badau, } 18 \\
\text { April } 2004\end{array}$ & $\begin{array}{l}\text { Desa } \\
\text { Sebindang }\end{array}$ & Islam & Islam & Melayu \\
\hline 3. & Dwi Putri & $\begin{array}{l}\text { Putussbau, } \\
21 \\
\text { Oktober } \\
2002\end{array}$ & Badau & Islam & $\begin{array}{l}\text { Islam } \\
\text { (Muallaf) }\end{array}$ & Melayu \\
\hline 4. & Erni Aprianti & $\begin{array}{l}\text { Badau, } 2 \\
\text { Juni } 2002\end{array}$ & $\begin{array}{l}\text { Tanjung } \\
\text { Permai }\end{array}$ & Islam & Islam & Melayu \\
\hline 5. & $\begin{array}{l}\text { Jumanah } \\
\text { Ashari }\end{array}$ & $\begin{array}{l}\text { Pontianak, } \\
14 \\
\text { Februari, } \\
2003\end{array}$ & Badau Hulu & Islam & Islam & Melayu \\
\hline 6. & $\begin{array}{ll}\text { Reski } & \text { Raka } \\
\text { Siwi } & \end{array}$ & $\begin{array}{l}\text { Badau, } 20 \\
\text { Maret } \\
2003\end{array}$ & Badau & Islam & Islam & Melayu \\
\hline 7. & Pendi Supendi & $\begin{array}{l}\text { Badau 9 } \\
\text { September } \\
2004\end{array}$ & Badau Hilir & Islam & Islam & Melayu \\
\hline
\end{tabular}

\section{Proses Bimbingan Keagamaan melalui Teknik Menulis}

Pelaksanaan bimbingan kelompok dengan teknik menulis berlangsung sebagaimana tahapan yang ada dalam bimbingan kelompok, yakni; (1) pembentukan kelompok, (2) identifikasi peran dan tujuan kelompok, (3) produksivitas, (4) relasi, (5) dan penutupan (oleh Gibson \& Mitchell, 2010). Proses tersebut berjalan selama dua siklus yang terdiri dari enam kali pertemuan.

1. Proses dalam siklus pertama

Proses siklus pertama berlangsung selama pertemuan pertama, kedua dan ketiga. Berdasarkan hasil evaluasi yang telah dilakukan dari peleksanaan bimbingan kelompok. Pada siklus ini anggota kelompok masih dalam tahap mengenal dan mengungkapkan berkenaan dengan informasi yang diberikan pemimpin kelompok. Ini dilakukan melalui kegiatan menulis dan diskusi. Berikut adalah proses pelaksanaan teknik menulis melalui bimbingan kelompok pada siklus pertama: a) Pertemuan pertama merupakan tahapan awal, pemimpin kelompok memberikan gambaran tentang pelaksanaan bimbingan, menyepakati jadwal dan durasi pertemuan. Perkenalan dilakukan secara lisan kemudian dilanjutkan dengan kegiatan menuliskan tentang diri sendiri berdasarkan arahan yang diberikan 
pemimpin kelompok (lihat tabel 1). Kegiatan bimbingan dilakukan dengan berdiskusi dan membacakan apa yang telah ditulis. Dalam tahapan ini anggota kelompok diarahkan untuk mengungkapkan bagaimana ia mengenal diri dan keinginannya. Apakah yang telah ia tulis telah dilaksanakan. Pemimpin kelompok membuat konseli nyaman dan mendorong konseli untuk melangkah pasti; b) Pertemuan kedua telah memasuki tahap kedua dalam bimbingan kelompok. Pengidentifikasian peran dan tujuan kelompok mulai ditampilkan. Pemimpin kelompok mengarahkan konseli untuk menuliskan pengalaman beragama yang paling berkesan dan paling membekas di dalam diri (lihat tabel 1). Pada tahap ini pemimpin kelompok menuntun anggota kepada arah tujuan kelompok yakni, mengenali fitrah beragama. Melalui proses penulisan pengalaman keagamaan anggota kelompok dengan sendirinya dapat mengidentifikasi posisi Allah di dalam kehidupan yang tengah dijalani saat ini; c) Pertemuan ketiga telah memasuki tahap produktivitas. Koseli telah mencatat kegiatan keagamaan apa saja yang biasa dilakukan, membuat gambaran tentang apa dan bagaimana yang harus ia lakukan untuk memenuhi fitrah beragama yang telah disadari keberadaannya. Dalam pelaksanaannya konseli diberikan tema tulisan mengapa harus berdoa, sebelum memulai diskusi anggota kelompok diberikan materi berjudul bantuan memahami zikir dan doa. Selanjutnya mulai membicarakan perencanaan-perencanaan perubahan atas beberapa sisi kehidupan yang dirasa perlu diperbaiki.

\section{Proses dalam Siklus Dua}

Siklus kedua terdiri dari tiga kali pertemuan, yakni pertemuan keempat, kelima dan keenam. Pada siklus kedua anggota kelompok diberikan tema tulisan yang sama dengan siklus pertama (Lihat tabel 1). Dalam kegiatan diskusi, anggota kelompok lebih mengarah kepada kegiatan membuat perencanaan untuk merealisasikan keinginan yang telah diungkapkan. Adapun pertemuan dilakukan sebagai berikut: a) Pertemuan pertama siklus kedua masih berada dalam tahap produktivitas kelompok bimbingan. Di mana anggota kelompok diarahkan untuk kembali mengenali dirinya melalui arahan pemimpin kelompok (Lihat tabel 1). Dalam tulisannya anggota kelompok mendefinisikan diri dan keinginan. Isi tulisan mengarah pada kefokusan membuat perencanaan pribadi yang akan dilakukannya untuk menjadi apa yang ia inginkan sebagaimana yang telah ditulis. Dalam tahap ini konseli telah mampu mengeksplorasi, memahami diri dan permasalahan yang dihadapi; b) Pertemuan kedua siklus kedua. Pada pertemuan ini telah memasuki tahap keempat, yakni tahap relasi. Anggota kelompok diarahkan untuk mengenali kesenjangan di masa lampau 
melalui kegitan menulis. Mengingat kembali di mana posisi Tuhan ketika mereka berada di dalam masalah, sebetulnya apa yang diinginkan, tapi apa yang dilakukan. Kemudian apa yang dirasakan. Hasil dari pertemuan kelima ini, anggota kelompok menyakinkan diri untuk melangkah pasti bertindak mengambil tanggung jawab. Anggota kelompok mengakui kesenjangan yang pernah dilakukan di masa lampau, menyadari hal tersebut sebagai sisi kehidupan yang perlu diperbaiki. Selanjutnya Anggota kelompok dibimbing untuk membuat rencana-rencana perbaikan; c) Pertemuan ketiga siklus kedua. Pada tepertemuan terakhir kelompok bimbingan dan tiap-tiap konseli telah sampai pada tujuan masingmasing. Melalui tema tulisan mengapa harus beribadah, anggota kelompok menuangkan perasaan beragamanya sebagai sesuatu yang fitrah. Demikianlah tujuan kelompok, yakni memberikan pemahaman tentang fitrah beragama dan membatu konseli menemukan jalan apa yang akan ditempuh untuk menjalankan fitrah beragamanya. Sementara itu, anggota kelompok telah membuat perencanaan dan ada pula yang telah menjalankan rencanarencana dalam kehidupan sehari-hari.

\section{Hasil Pelaksanaan Bimbingan Keagamaan Melalui Teknik Menulis}

Hasil bimbingan keagamaan menampilkan adanya kesadaran beragama pada siswa muslim di SMA Negeri 1 Badau setelah mengikuti bimbingan keagamaan melalui teknik menulis. Anggota kelompok bimbingan mampu mengenali dan menyadari permasalahan yang tengah mereka hadapi. Berikut adalah paparan hasil penggunaan teknik menulis dalam bimbingan kelompok yang terdiri dari dua siklus:

\section{Pertemuan Pertama di Siklus Satu dan Dua}

Pertemuan pertama, konseli diarahkan untuk mengenali diri dan keinginannya. Tindakan ini dilakukan sebagai langkah awal membawa konseli/anggota kelompok untuk memperhatikan diri dan menghayati keinginan yang kerapkali terabaikan. Hasilnya menunjukkan bahwa pada pertemuan pertama di siklus pertama, 1 dari 7 siswa melibatkan Allah dalam pengenalan dirinya. Ini dapat dilihat dari pernyataan yang dibuat di dalam tulisannya. Nur Fadila (konseli) menyatakan bahwa ia memiliki ilmu, usaha, niat tekad dan tidak lupa untuk selalu berdoa. Sementara 6 siswa lainnya secara umum menyatakan bahwa ia memiliki ilmu, niat, tekad dan kedua orangtua, tanpa menyertakan Allah di dalam tulisannya.

Secara keseluruhan keinginan dan tujuan hidup yang dibuat oleh tiap-tiap anggota kelompok adalah ingin menjadi sesuatu yang bermanfaat bagi msyarakat dan orangtua. Hal 
ini sejalan dengan fitrahnya sebagai manusia yang pada dasarnya baik dan selalu ingin memberikan yang terbaik.

Kemudian pada pertemuan pertama di siklus kedua, 5 konseli lainnya, menunjukkan perubahan yang signifikan dalam pengenalanan dirinya terhadap kesadaran beragama, ini dapat dilihat dari beberapa pernyataan konseli, di antaranya adalah pernyataan Jumana Ashari (konseli) "aku merasa akhlakku tidak baik. Jadi, mulai saat ini aku belajar untuk mengubah akhlakku dan saat ini aku mulai mendekatkan diri kepada Allah dan mulai melaksanakan perintah-Nya seperti salat, mengaji dan berdoa". Sementara itu Dwi Putri telah meletakkan posisi Tuhan dalam tujuan hidupnya, "Dan aku mempunyai tujuan hidup untuk membanggakan kedua orangtuaku, untuk membalas jasa kedua orangtua. Dan ingin patuh terhadap semua perintah dan larangan-larangan yang Allah berikan untuk hamba hamba-Nya."

Dari sini nampak jelas bahwa di dalam diri manusia terdapat kesiapan alamiah untuk menerima Allah dan mengesakan-Nya. Pengakuan terhadap kedudukan Allah sebagai Tuhan di dalam kehidupannya telah tertanam kuat sebagaimana kesaksian tiap-tiap manusia sebelum dilahirkan ke dunia.

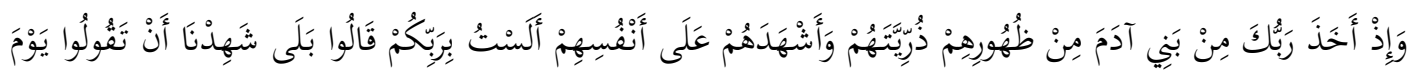

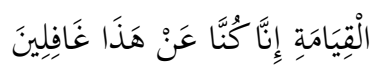

Dan (ingatlah), ketika Tuhanmu mengeluarkan keturunan anak-anak Adam dari sulbi mereka dan Allah mengambil kesaksian terhadap jiwa mereka (seraya berfirman): "Bukankah Aku ini Tuhanmu?" Mereka menjawab: "Betul (Engkau Tuhan kami), kami menjadi saksi". (Kami lakukan yang demikian itu) agar di hari kiamat kamu tidak mengatakan: "Sesungguhnya kami (bani Adam) adalah orang-orang yang lengah terhadap ini (keesaan Tuhan)" (Qs. Al -'Araf: 172).

\section{Pertemuan Kedua di Siklus Satu dan Dua}

Pertemuan kedua di siklus pertama, konseli diarahkan untuk menulis dengan tema "apa itu agama". Pada proses mengenali permasalahannya, remaja membutuhkan media untuk mengungkapkan kebingungan-kebingungan atau permasalahan yang tidak pernah dipikirkan. Dalam kegiatan menulis secara tidak langsung akan membawa remaja memikirkan tentang perkara agama.

Beberapa konseli mendefinisikan tentang agama di antaranya, Reski Raka Siwi memahami agama sebagai sesuatu yang mengajarkan hal-hal tentang hidup di jalan Allah. Sementara itu, Dwi Putri menyatakan bahwa agama adalah suatu keyakinan atau kepercayaan setiap orang. 
Dalam sesi diskusi beberapa anggota kelompok antusias mempertanyakan tentang perbedaan agama "Mengapa kita diciptakan beda agama? Mengapa tidak ada satu agama saja? Sedangkan Nabi Adam dan Hawa diciptakan sebagai sepasang dengan satu keyakinan, mengapa keturunannya membuat agama? Kemudian mendiskusikan tentang batas-batas toleransi dan memahami makna toleransi sebagai bentuk rasa saling menghargai bukan upaya mentiadakan aturan dan perbedaan.

Pertemuan kedua di siklus kedua, konseli menceritakan pengalaman beragama dan kondisi lingkungan masyarakat tempat tinggal, baik tentang perihal kebiasaan mabukmabukan dan tempat pelacuran yang dibuka secara terang-terangan di Badau. Anggota kelompok menilai hal tersebut sebagai perbuatan yang salah dan tidak pantas diikuti. Namun konseli mengakui banyak yang tidak mereka ketahui perihal agama, sebagaimana yang diungkapkan Adiel Candra (konseli) di dalam tulisannya "Jika ditanya soal agama aku sepenuhnya tidak tau. Setiap hari juga mulai memperbaiki diri, mulai dari ucapan. Ya, walau pun masih ceplas-ceplos. Aku juga masih sedikit tau tentang baik buruk sesuatu. Ya namanya masih belajar, itu pun dari orang-orang yang hanya sekadar mengingatkan buruk sesuatunya."

\section{Pertemuan Ketiga di Siklus Satu dan Dua}

Pertemuan ketiga di siklus pertama, siswa diarahkan untuk menulis dengan tema "Mengapa harus beribadah". Konseli menuliskan ibadah apa saja yang biasa mereka lakukan, 4 dari 6 siswa pada siklus pertama mengakui jarang beribadah dengan berbagai alasan yang berbeda, namun semuanya tidak benar-benar lepas dari kehidupan beragama, berdasarkan tulisan dan hasil diskusi semua konseli telah biasa melaksanakan salat, walau tidak lima waktu dan tidak konsisten setiap hari. Berikut adalah tulisan Adiel Candra pada pertemuan ke tiga di siklus pertama:

Kehidupan beribadahku seperti biasa, terkadang salat terkadang tidak, bahkan sampai diabaikan begitu saja. Pernah terlintas di benak "mengapa" mengapa harus beribadah? Seiring berjalannya waktu, aku mencari jawaban dari berbagai orang, berbagai macam jawaban pun aku dapatkan. Malas, bosan, dan cuek terhadap ibadah selalu aku lakukan. Aku selalu berpikir untuk melakukan ibadah, tetapi selalu dikalahkan oleh rasa malas, bosan dan cuek tersebut. Aku juga selalu merasa bersalah, berdosa bahkan merasa terhina karena tidak melakukan ibadah. Aku berpikir selalu untuk melakukan ibadah tersebut.

Akhir-akhir ini sesalu berpikir tentang beribadah dan memomohon kepada Allah SWT., mencoba untuk memperbaiki diri lewat ucapan walau terkadang ceplas ceplos, melalui sikap walaupun susah untuk dikendalikan. 
Hari ke hari aku tetap mencari jawaban, mengapa harus beribadah, mengapa harus tetap berdoa, mengapa adarasa malas untuk beribadah. Mengapa harus tetap berdoa, dan mengapa ada rasa malas beribadah. Ternyata semuanya ada pada diri sendiri, aku perlu mengubah sikap malasku menjadi sebuah semangat untuk beribadah.

Sebagai seorang muslim aku harus lebih meperbaiki diri dengan baik. Menjadikan Alquran sebagai pedoman, menjadikan salat sebagi kebiasaan dan menjadikan rasa malas sebagai semangat beribadah.

Semua bergantung pada waktu. Jika waktu hidupku masih dipanjangkan, maka pertamakali aku ingin memantapkan niatku untuk berubah, lebih giat beribadah lagi.

Dalam tulisannya Adiel mengungkapkan rasa malas yang mendominasi dirinya untuk beribadah. Dia mempertanyakan mengapa ada rasa malas, bosan dan cuek yang timbul dari dalam dirinya, kemudian ditemukannya jawaban bahwa semuanya terletak pada diri sendiri, Adiel menyadari bahwa ia harus mengubah sikap malasnya menjadi sebuah semangat untuk beribadah.

Pada siklus kedua, terjadi perubahan siswa mulai menunjukkan proses perubahan dengan meningkatnya intesistas beribadah. Satu di antaranya adalah Nur Fadila (konseli). Berikut adalah penggalan tulisan Nur Fadila;

Menurut saya ibadah adalah suatu keharusan bagi umat yang beragama. Ibadah sendiri bagi saya adalah suatu kebutuhan batin yang menjadi keharusan serta kewajiban bagi setiap individu.

Akhir-akhir ini ibadah yang saya lakukan ialah puasa sunnah Senin dan Kamis, serta selalu menjaga salat. Dorongan dari dalam diri menjadi pemicu yang menguatkan niat saya dalam beribadah.

Sementara itu Dwi Putri (konseli) telah berhasil menjaga intensitas beribadahnya dalam beberapa hari terakhir, hal ini diungkapkannya di dalam tulisan terakhir di siklus ke dua;

Dalam beberapa hari ini alhamdulillah aku sudah memenuhi salat 5 waktu. Dan semoga ke depannya jauh lebih baik lagi dalam menjalankan kewajiban dan perintahperintah yang Allah SWT., berikan. Dan aku harus menjalankan ibadah tersebut dengan niat dan belajar lagi hal yang menyangkut tentang agama Islam.

Sejalan dengan Dwi Putri dan Nur Fadila, Erni Aprianti (konseli) menyatakan bahwa ibadah merupakan salah satu jalan hidup untuk membawa diri kepada surga Allah, dalam keadaan apa pun utamakan ibadah, maka hidup akan jauh lebih bermakna.

Begitulah proses-proses yang dilalui oleh tiap-tiap anggota kelompok bimbingan. Kemudian ditemukan peerubahan setelah mengikuti bimbingan kelompok. Perubahan yang nampak dari ketika dilihat dari hasil pelaksanaan bimbingan di siklus satu dengan siklus 
dua. Secara umum hasilnya menunjukkan perubahan dalam pemposisian pentingnya agama, dalam kesadaran mereka untuk menjalankan atau pun perencanaan pelaksanaan menjalankan kehidupan beragama sebagai seorang muslim.

Terdapat perubahan setelah mengikuti bimbingan kelompok. Perubahan yang nampak dari ketika dilihat dari hasil pelaksanaan bimbingan di siklus satu dengan siklus dua. Secara umum hasilnya menunjukkan perubahan dalam pemposisian pentingnya agama, dalam kesadaran mereka untuk menjalankan atau pun perencanaan pelaksanaan menjalankan kehidupan beragama sebagai seorang muslim.

Hasil akhir dari kegiatan bimbingan keagamaan yang telah dilakukan adalah sebagai berikut: 1 anggota kelompok memutuskan untuk memantapkan niat sebagai pondasi perubahan, 4 orang anggota kelompok proses memperbaiki ibadah dan 2 orang anggota kelompok telah berusaha untuk mempertahankan amal ibadah yang mereka lakukan sebagai seorang muslim. Kemudian setiap anggota kelompok membuat langkah-langkah perubahan yang harus ditempuh. Guna menjalankan kehidupan beragama sebagai seorang muslim.

Terpacunya semangat untuk melakukan perubahan ini wajar terjadi, karena melalui kegiatan menulis di atas kertas merupakan salah satu langkah mengungkapkan suatu peristiwa, emosi, perasaan yang terpendam agar dapat dipahami atau dimengerti. Ini bertujuan untuk mengenali serta menyadari keberadaan problem yang ada di dalam diri. Sehingga dapat menentukan langkah-langkah yang harus ditempuh.

Pelaksanaan bimbingan dan konseling dengan teknik kreatif merupakan salah satu cara yang dapat ditempuh oleh konselor dalam mengembangkan gaya konseling kelompok sebagai upaya pemberian bantuan yang efektif. Sebagaimana yang dikatakan Jacobs (1994) konseling tidak memulu hanya berbicara tetapi kadangkala perlu melakukan.

\section{KESIMPULAN}

Berdasarkan hasil bimbingan keagamaan melalui teknik menulis yang dilakukan terhadap siswa muslim di perbatasan Indonesia-Malaysia (Badau-Lubok Antu), Kalimantan Barat, maka dapat disimpulkan bahwa hasil bimbingan keagamaan yang dilakukan secara terstruktur menunjukkan adanya kesadaran beragama pada siswa muslim SMA Negeri 1 Badau. Anggota kelompok bimbingan konseling mampu megenali dan menyadari permasalahan yang tengah mereka hadapi. Terdapat 1 anggota kelompok memutuskan untuk memantapkan niat sebagai pondasi perubahan, 4 orang anggota kelompok proses memperbaiki ibadah dan 2 orang anggota kelompok telah berusaha untuk mempertahankan amal ibadah yang mereka lakukan dalam menjalankan perintah Allah SWT. Kemudian 
beberapa anggota kelompok membuat langkah-langkah perubahan yang harus ditempuh.

Guna menjalankan kehidupan beragama sebagai seorang muslim.

\section{DAFTAR RUJUKAN}

Arifin, B.S. (2008). Psikologi Agama. Bandung: Pustaka Setia.

Faqih, A. R. (2001). Bimbingan dan Konseling dalam Islam. Jogyakarta: UII Press.

Geldard, K \& Geldard, D. (2015). Membantu Memecahkan Masalah Orang Lain dengan Teknik Konseling. Terj. Agung Prihantoro. Yogyakarta: Pustaka Pelajar.

Gunawan, A. W. (2012). The Miracle Of Mindbody Medicine How to use Yourr Mind for Better Health. Jakarta: Gramedia.

Jacobs, E. E. (1994). Creative Counseling Techniques. USA: Library of Congress Cataloging-in-Publication Data.

Karyanti, K., \& Setiawan, M. A. (2019). Pengembangan Model Simboling Kelompok Expressive Writing berlandaskan Falsafah Dandang Tingang untuk Meningkatkan Perilaku Respect. Anterior Jurnal, 18(2), 121-126.

Konadi, H., Mudjiran, \& Karmeli, Y. (2017). Efektivitas Pendekatan Emotive Behavior Therapy melalui Bimbingan Kelompok untuk Mengatasi Setres Akademik Siswa. Konselor, 6(4). 120-131.

Kurnanto, M. E. (2014). Konseling Kelompok. Jakarta. Alfabeta.

Lestari, M. A. \& Eliyanti, M. (2014). Efektivitas Penggunaan Teknik Menulis Ekspresif Dalam Mereduksi Stres Siswa Kelas X SMA (Penelitian Tindakan terhadap Siswa Kelas X SMA Angkasa LANUD Husein Sastranegara Bandung Tahun Ajaran 2013/2014). Jurnal Penelitian Pendidikan, 4(1), 1-20.

Pannebaker, J. \& Beall. (1986). Confronting a Traumatic Event: Toward and Understanding of Hibition and Dease. Journal of Abnorma Psychologhy, 95(3): 274-285.

Prastowo, A., (2011). Memahami metode-metode penelitian. Jogjakarta: Ar-Ruzz Media.

Gibson, R. L. \& Mitchell, M. H. (2010). Bimbingan dan Konseling. Yogyakarta: Pustaka Pelajar.

Samsudin, M. R. B. (2018). Terapi menulis dalam meningkatkan self Cofidence Seorang Mahasiswi Universitas Islam Negeri Sunan Ampel Surabaya. (Unpublished thesis) UIN Sunan Ampel Surabaya, Surabaya, Indonesia.

Subandi. (2013). Psikologi Agama dan Kesehatan Mental. Yogyakarta: Pustaka Pelajar.

Saripaini. (2020). Teknik Menulis mlalui Bimbingan Kelompok untuk Mencegah Problem Keagamaan di SMA Negeri 1 Badau, Klimantan Barat. Skripsi IAIN Pontianak, Pontianak, Indonesia.

Susanti, R., \& Supriyantini, S. (2013). Pengaruh expressive writing therapy terhadap penurunan tingkat kecemasan berbicara di muka umum pada mahasiswa. Jurnal Psikologi, 9(2), 119-129. 